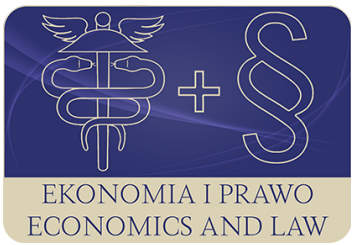

EKONOMIA I PRAWO. ECONOMICS AND LAW

Volume 19, Issue 4, December 2020

p-ISSN 1898-2255, e-ISSN 2392-1625

www.economicsandlaw.pl

EKONOMIA I PRAWO
ECONOMICS AND LAW

ORIGINAL ARTICLE

received 12.03.2020; revised 22.04.2020; accepted 31.12.2020

Citation: Karbowski, A. (2020). Schumpeterian hypothesis revisited: on market structure and firms'

R\&D. Ekonomia i Prawo. Economics and Law, 19(4): 699-712. doi:10.12775/EiP.2020.045.

\title{
Schumpeterian hypothesis revisited: on market structure and firms’ R\&D
}

\author{
ADAM KARBOWSKI \\ SGH Warsaw School of Economics, Collegium of World Economy, Department of Business \\ Economics, Al. Niepodległości 162, 02-554 Warszawa, Poland \\ $\square$ adam.karbowski@sgh.waw.pl \\ (D) orcid.org/0000-0002-8725-1616
}

\begin{abstract}
Motivation: This article sets out to clearly elaborate upon the relationship between market structure and firms' R\&D — the problem formulated by Joseph Schumpeter and widely discussed in the history of economic thought.

Aim: This paper aims to explain the main controversies which occurred in economic literature over the Schumpeterian hypothesis.

Results: The sources of controversies mentioned above are identified. Those controversies boil down to the following points: (1) 'early' or 'late' Schumpeter, (2) firm size or market power, (3) demand-side or supply-side arguments, (4) structure in R\&D stage or structure in product market stage, (5) type of $\mathrm{R} \& \mathrm{D}$ considered (process or product). The classification of standpoints on the relationship between market structure and firms' R\&D is proposed. The above classification allows to understand complexity of the 'market-R\&D'

links, and avoid at least some controversies over the Schumpeterian hypothesis.
\end{abstract}

Keywords: Schumpeterian hypothesis; market structure; firms' Red; economic thought JEL: B21; L11; O31; O32

\section{Introduction}

As Dolfsma \& van der Velde (2014) observe, the question which type of market structure promotes firms' R\&D has drawn much attention from both academic economists and policy makers. Schumpeter $(1911 ; 1934 ; 1942)$ pioneered the research on the relationship between market structure, firms' R\&D, and industrial innovation. Interestingly enough, Schumpeter's answer to the ques- 
tion which type of market structure spurs corporate $R \& D$ initiated a heated and long-standing economic debate which includes quite a lot of misunderstandings and controversies.

The aim of this paper is twofold. First, the purpose of this article is to distinguish between the answer given by 'early Schumpeter' (Schumpeter, 1911) and the answer given by 'late Schumpeter' (Schumpeter, 1942) to the question about market structure and firms' R\&D. As shown further in this paper, those answers constitute completely different ideas. The second aim of this article is to explain the main controversies which occurred in economic thought over Schumpeterian hypothesis. To achieve the above goals, the large body of economic literature from 1911 to 2020 is reviewed.

The paper proceeds as follows. The next section presents the method. Section 3 is devoted to Schumpeter's answers to the question of market structure and firms' R\&D. The ideas of 'early' and 'late' Schumpeter are there presented. Further, the influential Arrow's standpoint opposed to the Schumpeterian one is discussed. The subsequent section explores the answers given to the Schumpeter's question by d'Aspremont \& Jacquemin (1988), and their followers. The sixth section presents the results. Section 7 concludes the article.

\section{Methods}

The present paper constitutes a comprehensive review article on the Schumpeterian hypothesis and its evolution in the history of economic thought. The main voices in the heated economic debate on the relationship between market structure and firms' R\&D are here presented and discussed. The large body of literature from 1911 to 2020 is reviewed in an informed manner. The sophisticated concepts are illustrated with the original graphical models. The various standpoints on the relationship between market structure and firms' R\&D are further classified and succinctly presented in tables. This article reconstructs the long-standing debate on the Schumpeterian hypothesis, and serves as an invitation to a further discussion on the topic.

\section{Schumpeterian hypothesis}

Surprisingly, there are quite a lot of controversies over the Schumpeterian hypothesis (Acs \& Audretsch, 1988; Andersen, 2009; Braunerhjelm \& Svensson, 2010; Breschi et al., 2000; Czegledi, 2017; Dhanora et al., 2020; Kamien \& Schwartz, 1982; Lee \& Sung, 2005; Nelson, 1990; Schneider, 1975; Schumpeter, 1934; 1942; Tirole, 1988).

First, it is worth underlining that Schumpeter's thinking about the relationship between market structure and firms' R\&D evolved over time (Acs \& Audretsch, 1988; Andersen, 2009; Nelson \& Winter, 1982). The historians of economic thought distinguish between Schumpeter Mark I (ideas of 'early 
Schumpeter') and Schumpeter Mark II (ideas of 'late Schumpeter') positions (Dolfsma \& van der Velde, 2014; Malerba, 2002).

Schumpeter as a young researcher (at the age of 28 years) published in German The theory of economic development (the book appeared in 1911, see the English version, 1934), where the innovative $R \& D$ is linked to the entrepreneurial firm new to the market. The conceptual model of Schumpeter's thinking from 1911 is given in scheme 1 .

\subsection{Ideas of 'early Schumpeter'}

The central role in the evolution of the economic system is given by Schumpeter (1934; Andersen, 2009) to the entrepreneur. According to Schumpeter, the entrepreneur is a man of action who is (1) not the capitalist (banker), (2) not the bearer of the economic risk, (3) not the manager of the firm, and (4) not the inventor. The Schumpeterian entrepreneur is a creative person who sets up a new firm based on the invention made by the inventor. The entrepreneurs are persons with a specific kind of intelligence, energy and leadership which are only in a minority of economic agents (Andersen, 2009; Schneider, 1975; Schumpeter, 1934).

The new firm is financed through credit given by the banker who is motivated by the share in the firm's expected supernormal profit (Andersen, 2009). As we can see, the entrepreneur and the following R\&D-based innovation are dependent in the Schumpeterian system on the ideas of inventors and credits given by the capitalists. Inventions are novel devices or production methods which are not obvious to experts in the given field (Parayil, 1991). According to Schumpeter, inventions appear without interruption, so they constitute a continuous economic process (in contrast to discrete processes which take place in the economy) (Andersen, 2009).

New firm established by the entrepreneur performs R\&D works and further introduces the innovation in the marketplace. In the Schumpeterian system, innovation is not just an invention. Not all inventions can be transformed into innovations successfully commercialised in the competitive market. Schumpeter distinguishes five types of innovation - process (a change of the production routine), product (a new type of product), organisational (a change in the routine underlying behaviour in the firm), market (an introduction of a product used routinely by one group of consumers into the consumption routine of a different group of consumers), and input (a new raw material) (Andersen, 2009; Schneider, 1975). Innovations appear with interruptions, so they constitute a discrete economic process. The financial outcome of an innovation is the supernormal profit earned by the entrepreneurial firm. The supernormal profit allows to repay the banker the credit with interest.

The banker gives next the potential imitators credits. The potential imitators are the market incumbents and competitors of the entrepreneurial firm. They are interested in having the same technology which now belongs to the entrepre- 
neurial firm. The innovative behaviour of the entrepreneurial firm and the imitative behaviour of incumbent firms initiate the process of creative destruction (Schumpeter, 1934) of the routinised economic order. The process diverts the means of production from previous uses, forces the routinised economy onto new paths, and eventually leads to the new state of a stationary equilibrium (Andersen, 2009; Schneider, 1975). The creative destruction annihilates firms which cannot challenge their routines and adapt to the new market conditions.

The economy in the stationary form consumes entirely the net national product (investments equal depreciation of capital) (Andersen, 2009; Schneider, 1975; Schumpeter, 1934).

Based on Schumpeter $(1911 ; 1934)$, we thus can formulate the early version of Schumpeter's hypothesis $(\mathrm{SHl})$ : the R\&D-based competition between entrepreneurial firm and incumbent firms determines a supply of innovations in the marketplace.

\subsection{Ideas of 'late Schumpeter'}

Schumpeter (1942) presented a significantly modified concept of the market structure and firms' R\&D (see, scheme 2). The roles of inventors, bankers, entrepreneurs and their innovative firms have been replaced with the functions of large monopolistic corporations (Acs \& Audretsch, 1987; 1988; Andersen, 2009; Cohen \& Klepper, 1996). According to Schumpeter (1942), the large monopolistic firms internalised the activities of inventors, capitalists and entrepreneurs. The role of inventors has been taken over by the R\&D departments of large corporations. The role of bankers was no longer essential due to the accumulation of supernormal profits by the monopoly. Finally, the role of entrepreneurs has been taken over by corporate managers. In Schumpeter's (1942) view, monopolies can effectively capitalise on their resources (intellectual, financial, operational) and outcompete the other, less concentrated, market structures.

It is worth stressing that for 'late Schumpeter' the innovative process remained discrete, so the innovations were introduced by monopolies with interruptions. The adaptive process initiated by the introduction of an R\&D-based innovation was no longer a creative destruction, since no firms were annihilated in the monopolistic market.

Based on Schumpeter (1942), we can now formulate the late version of Schumpeter's hypothesis (SH2): the monopoly generates a larger supply of innovations due to advantages which, though not strictly unattainable on the competitive level, are as a matter of fact secured only on the monopoly level (Andersen, 2009; Schneider, 1975). 


\subsection{Firm size or market power}

The second serious controversy over the Schumpeterian hypothesis relates to the term 'monopolistic corporation' (Schumpeter, 1942). Some authors understood it as a (1) large size of a firm ('corporate bigness', see Tirole (1988), for a wider discussion), but some interpreted it as a (2) high market power. It is worth stressing that firms with a high market power, do not necessarily have to be large in size, measured by the value of assets, the value of sales, or the number of employees (see Fisher \& Temin, 1973; Karbowski, 2019; Lee \& Sung, 2005; Tirole, 1988). Schumpeter (1942) did not notice the above discrepancy, and treated monopolistic corporations as both large in size and with a high market power. Therefore, the authors who followed Schumpeter (1942) tested either the relationship between (1) firm size and R\&D or (2) market power and $\mathrm{R} \& \mathrm{D}$. The shortlist of representative authors and studies is given in table 1 .

The third bitter controversy over the Schumpeterian hypothesis relates to the choice of supply-side or demand-side arguments. Schumpeter (1942), again, did not distinguish any of the above classes of arguments. Schumpeter (1942) referred to both supply-side and demand-side advantages of the monopoly. However, such an approach was criticised by Galbraith (1952), who suggested the supremacy of the supply-side arguments (availability of all necessary resources at the monopoly level - intellectual, financial, commercial; economies of scale in R\&D projects; avoiding duplication costs). Arrow (1962), in turn, suggested that the demand-side arguments (incentives to undertake $R \& D)$ are supreme. The rigorous analysis of the demand side of the Schumpeterian hypothesis led Arrow to deny the hypothesis (SH2) itself. Based on the demand-side arguments, Arrow claimed that competition rather than monopoly promotes firms' R\&D (Baker, 2007).

\section{Arrow's standpoint}

Arrow (1962) analysed firms' incentives to perform R\&D works under different market structures (oligopolistic competition, monopoly, and social planner case). For those market structures, Arrow determined the value of an R\&Dbased innovation measured as a change in the discounted value of economic profits after the introduction of a process innovation (Karbowski, 2016). Arrow proved that the value of a process innovation for a monopoly is smaller than the value of a process innovation for an oligopolistic firm, and the value of a process innovation for an oligopolistic firm is smaller than the value of a process innovation for the social planner.

The value of an innovation constitutes an incentive to perform corporate $R \& D$ works. Since the value of an innovation under oligopolistic competition dominates the value of an innovation under monopoly, Arrow concluded that competition rather than monopoly spurs firms' $\mathrm{R} \& \mathrm{D}$ and corporate innovation. 
As Baker (2007) observes, a monopoly might perform less R\&D works than a competitive firm, because a monopoly has more to lose. Even if the monopolist spends a lot of money on R\&D and makes a radical innovation (Tirole, 1988), it cannot take over the market which was already controlled. In contrast, if the competitive firm invests in $R \& D$ and introduces a radical innovation, it takes over the market which was competitive. The above limitation on the incentive of the monopolist to perform R\&D works is called the 'replacement effect' (the monopoly via radical innovation can only replace itself, while the competitive firm can capture the previously competitive market) or the 'Arrow effect' (Baker, 2007; Shapiro, 2012).

Arrow's standpoint was further supported by economists who matched corporate R\&D investments with a relatively weak incumbency position (for reviews see Adner \& Kapoor, 2016; Christensen, 1997; Shapiro, 2012). Firms without a strong incumbency position usually have a greater incentive to invest in R\&D compared with the (often natural) monopolist because they are not tied to an installed base of customers (Adner \& Kapoor, 2016; Christensen, 1997; Shapiro, 2012). By contrast, firms with a strong incumbency position are often reluctant to invest in R\&D unless such investments allow to block potential entrants.

Arrow's standpoint has several limitations. First, Arrow's (1962) analysis takes into account only oligopolistic competition, and precisely, only Bertrand oligopolistic competition. Perfect competition, monopolistic competition or oligopolistic competition in a different style (Cournot, Stackelberg, price leadership) are neglected. Also, Arrow considers only process innovations. Though important, they are essentially different than the other types of innovation for which the adequate analysis is needed. Lastly, Arrow's reasoning almost completely omits the supply-side determinants of firms' R\&D investments and their interplay with the demand-side factors.

Despite all the above limitations, the Arrow's reasoning dominated the economic research on the relationship between market structure and firms' R\&D for more than 20 years. At least until 1988, and the publication of the seminal paper by d'Aspremont \& Jacquemin (1988).

\section{Standpoint of d'Aspremont \& Jacquemin (1988) and followers}

It is worth noticing that the structure of the product market (competition or monopoly) does not have to correspond to the structure of the corporate R\&D (non-cooperative or cooperative) which precedes the product market decisions. d'Aspremont \& Jacquemin (1988) were the first economists who decomposed the relationship between market structure and firms' R\&D into (1) R\&D stage and (2) product market stage. Thus, firms can, e.g., collude in R\&D decisions (coordinate R\&D investments and set them like a cartel or a monopoly) and compete in final product prices or quantities (product market competition). And the other way around, firms can compete in R\&D (set their R\&D invest- 
ments unilaterally) and collude in final product prices or quantities (product market cartel or monopoly).

The decomposition of the relationship between market structure and firms' R\&D allows to put the heated debate (Belleflamme \& Peitz, 2015) on competition and innovation on the right track. Above all, the exact market structures concerning both R\&D and production can be distinguished. The latter helps a lot in avoiding misunderstandings or confusion related to the competition-innovation debate. The possible combinations of $R \& D$ and product market decisions are given in table 2.

In $R \& D$ competition, firms decide on their $R \& D$ investments unilaterally to maximize their individual profits, and compete in prices or quantities in the product market. In $\mathrm{R} \& \mathrm{D}$ cartel/monopoly, firms coordinate their R\&D investments, but compete in the product market. In full cartel/monopoly, firms coordinate both their R\&D investments and product market decisions.

D’Aspremont \& Jacquemin (1988) proved that firms' process R\&D investments are higher under R\&D cartel/R\&D monopoly compared with R\&D competition if the level of knowledge spillovers in the industry is large enough. As Karbowski (2019) observed, in the presence of spillovers, the returns from corporate R\&D investments are not fully appropriable by the investing firms (Belderbos et al., 2018; Czarnitzki et al., 2007; Geroski, 1995; Karbowski, 2019). The knowledge leaks out to competitors, negatively affecting firms' incentives to undertake R\&D (Karbowski, 2019). Although the R\&D monopoly promotes process $R \& D$ compared with $R \& D$ competition, it is important to notice that the R\&D monopoly entails the risk of full industry cartelisation, at the cost of consumer welfare (Karbowski \& Prokop, 2018; Martin, 2006; Miyagiwa, 2009).

The process $R \& D$ investments under full monopoly/cartel were, in turn, always higher than the process $R \& D$ investments under $R \& D$ cartel/R\&D monopoly (d'Aspremont \& Jacquemin, 1988). The d'Aspremont \& Jacquemin (1988) results were replicated by Kamien et al. (1992) and Kamien \& Zang (2000). See also Belleflamme \& Peitz (2015), as well as confirmed empirically by Aschhoff \& Schmidt (2008), Becker \& Dietz (2004).

The above studies discussed process $R \& D$ investments. The relevant research on market structure and firms' R\&D in the context of product innovation was done by Karbowski (2019). The results of theoretical analysis present in the latter paper suggest that product $R \& D$ investments under $R \& D$ competition are higher (or in extreme cases equal to) than the product R\&D investments under R\&D cartel/R\&D monopoly or full monopoly/cartel. The above results are consistent with the empirical findings (Bouncken \& Kraus, 2013; Un et al., 2010).

\section{Results}

The heated discussion on the relationship between market structure and firms' $R \& D$ can be concisely presented in table 3 . First, in order to properly frame 
the discussion, we should distinguish between R\&D competition, R\&D monopoly, and full monopoly. Second, it is important to separate process R\&D from product $R \& D$. Then, we can show and classify different standpoints on the market structure and firms' R\&D.

Standpoint 1 is as follows - full monopoly spurs process R\&D (standpoint 1 consists of three degrees; $1+++$ denotes high process R\&D investment according to the authors who share standpoint $1 ; 1++$ denotes medium process $\mathrm{R} \& \mathrm{D}$ investment according to the authors who share standpoint $1 ; 1+$ denotes low process $R \& D$ investment according to the authors who share standpoint 1 ). Standpoint 2 is as follows - R\&D competition spurs process R\&D (standpoint 2 consists of two degrees; $2++$ denotes high process R\&D investment according to the authors who share standpoint 2; 2+ denotes low process R\&D investment according to the authors who share standpoint 2). Standpoint 3 is as follows $R \& D$ competition spurs product $R \& D$ (standpoint 3 consists of two degrees; $3++$ denotes high product $R \& D$ investment according to the authors who share standpoint 3; 3+ denotes low product R\&D investment according to authors who share standpoint 3 ). And finally, standpoint 4 is as follows - full monopoly spurs product R\&D (standpoint 4 consists of two degrees; 4++ denotes high product R\&D investment according to the authors who share standpoint $4 ; 4+$ denotes low product $\mathrm{R} \& \mathrm{D}$ investment according to the authors who share standpoint 4).

\section{Conclusion}

The purpose of this article was twofold. First, we aimed to clearly elaborate upon the relationship between market structure and firms' R\&D - the problem formulated by Schumpeter and widely discussed in the history of economic thought. We distinguished between the ideas of 'early Schumpeter' who suggested that competition spurs firms' R\&D and 'late Schumpeter' who found that product market monopoly enhances firms' R\&D in comparison with product market competition. Second, our goal was to explain the main controversies which occurred over Schumpeterian hypothesis in economic literature. We indicated and discussed the sources of controversies mentioned above: (1) 'early' or 'late' Schumpeter, (2) firm size or market power, (3) demand-side or supply-side arguments, (4) structure in R\&D stage or structure in product market stage, (5) type of R\&D considered (process versus product).

Finally, the classification of even opposite standpoints on market structure and firms' R\&D was proposed. As regards process $R \& D$, full monopoly dominates R\&D competition according to 'late Schumpeter', d'Aspremont \& Jacquemin (1988), and Kamien et al. (1992). R\&D competition dominates full monopoly according to Arrow. As regards product $\mathrm{R} \& \mathrm{D}$, full monopoly dominates R\&D competition according to 'late Schumpeter'. R\&D competition dominates full monopoly according to Karbowski (2019). The above classification can help understand complexity of the relationship between market structure 
and firms' R\&D, and avoid at least some future controversies or misunderstandings over the Schumpeterian hypothesis. Thus, this article can be useful both to theorists who construct mathematical models of market structure and corporate R\&D and empirical economists who econometrically test the Schumpeterian hypothesis. Lastly, this paper may also interest policy makers who make industrial policy.

\section{References}

Acs, Z.J., \& Audretsch, D.B. (1987). Innovation, market structure, and firm size. Review of Economics and Statistics, 69(4). doi:10.2307/1935950.

Acs, Z.J., \& Audretsch, D.B. (1988). Testing the Schumpeterian hypothesis. Eastern Economic Journal, 14(2).

Adner, R., \& Kapoor, R. (2016). Innovation ecosystems and the pace of substitution: re-examining technology S-curves. Strategic Management Journal, 37(4). doi:10.1002/smj. 2363.

Andersen, E. (2009). Schumpeter's evolutionary economics: a theoretical, historical and statistical analysis of the engine of capitalism. London: Anthem Press. doi:10.7135/UPO9781843313359.

Aschhoff, B., \& Schmidt, T. (2008). Empirical evidence on the success of R\&D cooperation: happy together. Review of Industrial Organization, 33(1). doi:10.1007/s11151-008-9179-7.

Arrow, K. (1962). Economic welfare and the allocation of resources for invention. In The rate and direction of inventive activity: economic and social factors. Princeton: Princeton University Press.

d'Aspremont, C., \& Jacquemin, A. (1988). Cooperative and noncooperative R\&D in duopoly with spillovers. American Economic Review, 78(5).

Baker, J. (2007). Beyond Schumpeter vs. Arrow: how antitrust fosters innovation. Antitrust Law Journal, 74.

Becker, W., \& Dietz, J. (2004). R\&D cooperation and innovation activities of firms: evidence for the German manufacturing industry. Research Policy, 33(2). doi:10.1016/j.respol.2003.07.003.

Belderbos, R., Gilsing, V., Lokshin, B., Carree, M., \& Sastre, J.F. (2018). The antecedents of new R\&D collaborations with different partner types: on the dynamics of past R\&D collaboration and innovative performance. Long Range Planning, 51(2). doi:10.1016/j.lrp.2017.10.002.

Belleflamme, P., \& Peitz, M. (2015). Industrial organization: markets and strategies. Cambridge: Cambridge University Press.

Bouncken, R.B., \& Kraus, S. (2013). Innovation in knowledge-intensive industries: the double-edged sword of coopetition. Journal of Business Research, 66(1). doi:10.1016/j.jbusres.2013.02.032.

Braunerhjelm, P., \& Svensson, R. (2010). The inventor's role: was Schumpeter right. Journal of Evolutionary Economics, 20(3). doi:10.1007/ s00191-009-0157-5. 
Breschi, S., Malerba, F., \& Orsenigo, L. (2000). Technological regimes and Schumpeterian patterns of innovation. The Economic Journal, 110(463). doi:10.1111/1468-0297.00530.

Choi, J., \& Lee, J. (2018). Firm size and compositions of R\&D expenditures: evidence from a panel of $\mathrm{R} \& \mathrm{D}$ performing manufacturing firms. Industry and Innovation, 25(5). doi:10.1080/13662716.2017.1297222.

Christensen, C. (1997). The innovator's dilemma. Boston: Harvard Business School Press.

Cohen, W. (1995). Empirical studies of innovative activity. In P. Stoneman (Ed.), Handbook of the economics of innovation and technological change. Oxford: Blackwell.

Cohen, W.M., \& Klepper, S. (1996). A reprise of size and R\&D. The Economic Journal, 106(437). doi:10.2307/2235365.

Czarnitzki, D., Ebersberger, B., \& Fier, A. (2007). The relationship between R\&D collaboration, subsidies and R\&D performance: empirical evidence from Finland and Germany. Journal of Applied Econometrics, 22(7). doi:10.1002/jae.992.

Czegledi, P. (2017). Productivity, institutions, and market beliefs: three entrepreneurial interpretations. Journal of Entrepreneurship and Public Policy, 6(2). doi:10.1108/JEPP-10-2016-0041.

Dhanora, M., Sharma, R., \& Jose, M. (2020). Two-way relationship between innovation and market structure: evidence from Indian high and medium technology firms. Economics of Innovation and New Technology, 29(2). doi:10. 1080/10438599.2019.1596575.

Dolfsma, W., \& van der Velde, G. (2014). Industry innovativeness, firm size, and entrepreneurship: Schumpeter Mark III. Journal of Evolutionary Economics, 24(4). doi:10.1007/s00191-014-0352-x.

Feichtinger, G., Lambertini, L., Leitmann, G., \& Wrzaczek, S. (2016). R\&D for green technologies in a dynamic oligopoly: Schumpeter, Arrow and inverted-U's. European Journal of Operational Research, 249(3). doi:10.1016/j. ejor.2015.09.025.

Fisher, F.M., \& Temin, P. (1973). Returns to scale in research and development: what does the Schumpeterian hypothesis imply. Journal of Political Economy, 81(1). doi:10.1086/260006.

Galbraith, J.K. (1952). American capitalism: the concept of countervailing power. Boston: Houghton Mifflin.

Geroski, P. (1995). Do spillovers undermine the incentive to innovate. In S. Dowrick (Ed.), Economic approaches to innovation. Aldershot: Edward Elgar.

Guichardaz, R., \& Penin, J. (2019). Why was Schumpeter not more concerned with patents. Journal of Evolutionary Economics, 29(4). doi:10.1007/ s00191-019-00633-y.

Kamien, M.I., \& Schwartz, N.L. (1982). Market structure and innovation. Cambridge: Cambridge University Press. 
Kamien, M.I., Muller, E., \& Zang, I. (1992). Research joint ventures and R\&D cartels. American Economic Review, 82(5).

Kamien, M.I., \& Zang, I. (2000). Meet me halfway: research joint ventures and absorptive capacity. International Journal of Industrial Organization, 18(7). doi:10.1016/S0167-7187(00)00054-0.

Karbowski, A. (2016). The elasticity-based approach to enterprise innovation. International Journal of Management and Economics, 49(1). doi:10.1515/ ijme-2016-0004.

Karbowski, A., \& Prokop, J. (2018). R\&D activities of enterprises, product market leadership, and collusion. Proceedings of Rijeka Faculty of Economics: Journal of Economics and Business, 36(2). doi:10.18045/zbefri.2018.2.735.

Karbowski, A. (2019). Cooperative and non-cooperative R\&D in product innovation and firm performance. Journal of Business Economics and Management, 20(6). doi:10.3846/jbem.2019.11050.

Kim, J., Lee, S.J., \& Marschke, G. (2009). Relation of firm size to R\&D productivity. International Journal of Business and Economics, 8(1).

Lafay, T., \& Maximin, C. (2017). How R\&D competition affects investment choices. Managerial and Decision Economics, 38(2). doi:10.1002/mde.2745.

Lambert, T.E. (2020). Monopoly capital and innovation: an exploratory assessment of R\&D expenditures. International Review of Applied Economics, 34(1). doi:10.1080/02692171.2019.1620703.

Lee, C.Y., \& Sung, T. (2005). Schumpeter's legacy: a new perspective on the relationship between firm size and R\&D. Research Policy, 34(6). doi:10.1016/j. respol.2005.04.006.

Li, S., Liu, Q., \& Refalo, J. (2019). Industry classification, product market competition, and firm characteristics. Finance Research Letters. Advance online publication. doi:10.1016/j.frl.2019.101319.

Link, A.N. (1980). Firm size and efficient entrepreneurial activity: a reformulation of the Schumpeter hypothesis. Journal of Political Economy, 88(4). doi:10.1086/260901.

Link, A.N., \& Scott, J.T. (2018). Propensity to patent and firm size for small R\&D-intensive firms. Review of Industrial Organization, 52(4). doi:10.1007/ s11151-018-9617-0.

Malerba, F. (2002). Sectoral systems of innovation and production. Research Policy, 31(2). doi:10.1016/S0048-7333(01)00139-1.

Mansfield, E. (1964). Industrial research and development expenditures: determinants, prospects, and relation of size of firm and inventive output. Journal of Political Economy, 72(4). doi:10.1086/258914.

Martin, S. (2006). Competition policy, collusion, and tacit collusion. International Journal of Industrial Organization, 24(6). doi:10.1016/j.ijindorg.2006.04.007.

Mason, E.S. (1951). Schumpeter on monopoly and the large firm. The Review of Economics and Statistics, 33(2). doi:10.2307/1925876.

Miyagiwa, K. (2009). Collusion and research joint ventures. The Journal of Industrial Economics, 57(4). doi:10.1111/j.1467-6451.2009.00399.x. 
Nelson, R.A. (1990). Productivity growth, scale economies and the Schumpeterian hypothesis. Southern Economic Journal, 57(2). doi:10.2307/1060628.

Nelson, R., \& Winter, S. (1982). The Schumpeterian tradeoff revisited. American Economic Review, 72(1).

Nicholas, T. (2003). Why Schumpeter was right: innovation, market power, and creative destruction in 1920s America. The Journal of Economic History, 63(4). doi:10.1017/S0022050703002523.

Quirmbach, H.C. (1986). The diffusion of new technology and the market for an innovation. The RAND Journal of Economics, 17(1). doi:10.2307/2555626.

Parayil, G. (1991). Schumpeter on invention, innovation and technological change. Journal of the History of Economic Thought, 13(1). doi:10.1017/ S1053837200003412.

Scherer, F.M. (1967). Market structure and the employment of scientists and engineers. American Economic Review, 57(3).

Schneider, E. (1975). Joseph A. Schumpeter: life and work of a great social scientist. Lincoln: University of Nebraska.

Schumpeter, J.A. (1911). Theorie der wirtschaftlichen Entwicklung. Leipzig: Verlag von Duncker \& Humblot.

Schumpeter, J.A. (1934). The theory of economic development: an inquiry into profits, capital, credit, interest and the business cycle. Cambridge: Harvard University Press.

Schumpeter, J.A. (1942). Capitalism, socialism and democracy. New York: Harper \& Brothers.

Shapiro, C. (2012). Competition and innovation: did Arrow hit the bull's eye. In J. Lerner \& S. Stern (Eds.), The rate and direction of inventive activity revisited. Chicago: Chicago University Press. doi:10.7208/ chicago/9780226473062.003.0011.

Shrieves, R. (1978). Market structure and innovation: a new perspective. Journal of Industrial Economics, 26(4). doi:10.2307/2098078.

Tirole, J. (1988). The theory of industrial organization. Cambridge: MIT Press.

Un, C.A., Cuervo-Cazurra, A., \& Asakawa, K. (2010). R\&D collaborations and product innovation. Journal of Product Innovation Management, 27(5). doi:10.1111/j.1540-5885.2010.00744.x.

Vossen, R.W. (1999). Market power, industrial concentration and innovative activity. Review of Industrial Organization, 15. doi:10.1023/A:1007727815408.

\section{Acknowledgements}

Author contributions: author has given an approval to the final version of the article.

Funding: this research was undertaken as part of the ReD cooperation of firms and competition on the product market project and was jointly funded by a grant from the National Science Centre in Poland (2017/25/B/HS4/01632). 


\section{Appendix}

\section{Table 1.}

\section{SH2 in the representative studies}

\begin{tabular}{cc}
\hline $\begin{array}{c}\text { SH2 interpreted as the relationship between firm size } \\
\text { and R\&D }\end{array}$ & $\begin{array}{c}\text { SH2 interpreted as the relationship between market } \\
\text { power and R\&D }\end{array}$ \\
\hline Choi \& Lee (2018) & Baker (2007) \\
Cohen (1995) & Feichtinger et al. (2016) \\
Dhanora et al. (2020) & Guichardaz \& Penin (2019) \\
Dolfsma \& van der Velde (2014) & Lambert (2020) \\
Fisher \& Temin (1973) & Li et al. (2019) \\
Galbraith (1952) & Mason (1951) \\
Kim et al. (2009) & Nicholas (2003) \\
Lee \& Sung (2005) & Quirmbach (1986) \\
Link \& Scott (2018) & Scherer (1967) \\
Link (1980) & Shrieves (1978) \\
Mansfield (1964) & Vossen (1999) \\
\hline
\end{tabular}

Source: Own preparation.

Table 2.

$\mathrm{R} \& \mathrm{D}$ and product market decisions

\begin{tabular}{|c|c|c|}
\hline R\&D behaviour & R\&D stage & Product market stage \\
\hline R\&D competition & $\begin{array}{l}\text { firms do not coordinate their } \mathrm{R} \& \mathrm{D} \\
\text { decisions }\end{array}$ & $\begin{array}{l}\text { competition between firms in the prod- } \\
\text { uct market }\end{array}$ \\
\hline R\&D cartel/R\&D monopoly & $\begin{array}{l}\text { firms coordinate their } \mathrm{R} \& \mathrm{D} \text { decisions } \\
\text { (in } \mathrm{R} \& \mathrm{D} \text { stage, firms behave like a car- } \\
\text { tel or a monopoly) }\end{array}$ & $\begin{array}{l}\text { competition between firms in the prod- } \\
\text { uct market }\end{array}$ \\
\hline full monopoly/cartel & $\begin{array}{l}\text { firms coordinate their } \mathrm{R} \& \mathrm{D} \text { decisions } \\
\text { (in } \mathrm{R} \& \mathrm{D} \text { stage, firms behave like a car- } \\
\text { tel or a monopoly) }\end{array}$ & $\begin{array}{l}\text { collusion in the product market } \\
\text { (in product market, firms behave like } \\
\text { a cartel or a monopoly) }\end{array}$ \\
\hline
\end{tabular}

Source: Own preparation based on: d'Aspremont \& Jacquemin (1988), Belleflamme \& Peitz (2015), Kamien \& Zang (2000), Kamien et al. (1992), Karbowski (2019), Lafay \& Maximin (2017).

Table 3.

\section{The classification of standpoints on market structure and firms' R\&D}

\begin{tabular}{ccc}
\hline R\&D behaviour & Process R\&D & Product R\&D \\
\hline \multirow{2}{*}{ R\&D competition } & $1+$ (d'Aspremont \& Jacquemin, 1988; Kamien \& Zang, 2000; & 3++ (Karbowski, 2019; \\
& Kamien et al., 1992; Schumpeter, 1942) & Schumpeter, 1911) \\
2++ (Arrow, 1962; Schumpeter, 1911) & $4+$ (Schumpeter, 1942) \\
R\&D monopoly & $1++$ (d'Aspremont \& Jacquemin, 1988; Kamien \& Zang, 2000; & 3+ (Karbowski, 2019) \\
& Kamien et al, 1992) & \\
full monopoly & $1+++$ (d’Aspremont \& Jacquemin, 1988; Kamien \& Zang, 2000; & 3+ (Karbowski, 2019) \\
& Kamien et al., 1992; Schumpeter, 1942) & $4++$ (Schumpeter, 1942) \\
\hline
\end{tabular}

Source: Own preparation based on: Arrow (1962), d'Aspremont \& Jacquemin (1988), Kamien \& Zang (2000), Kamien et al. (1992), Karbowski (2019), Schumpeter (1934; 1942). 
Scheme 1.

Schumpeter Mark I model

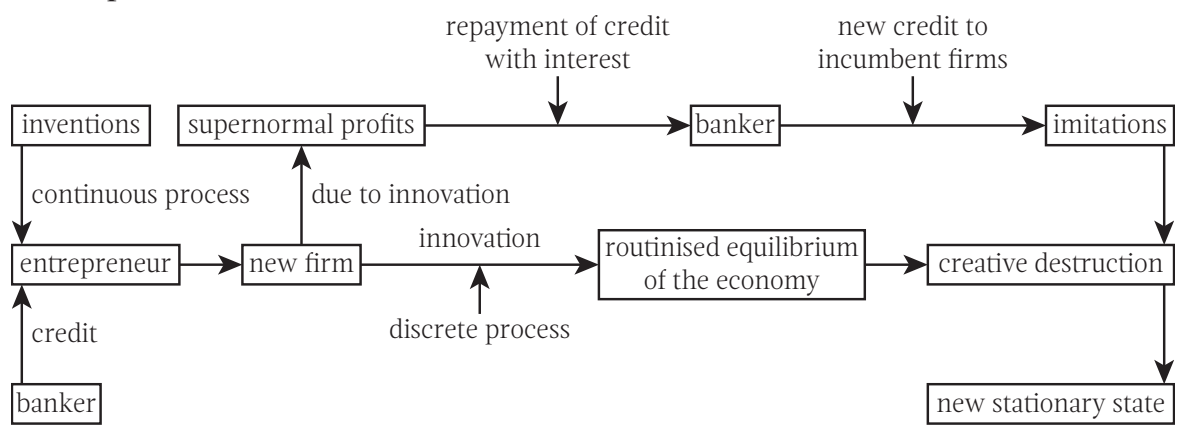

Source: Own preparation.

Scheme 2.

Schumpeter Mark II model.

\begin{tabular}{|c|c|c|c|}
\hline \multirow{2}{*}{ monopoly } & innovation & \multirow{2}{*}{$\begin{array}{c}\text { routinised equilibrium } \\
\text { of the economy }\end{array}$} & \\
\hline & discrete process & & \\
\hline
\end{tabular}

Source: Own preparation. 